Original article

\title{
Responses of soil ammonia oxidation and ammonia-oxidizing communities to land-use conversion and fertilization in an acidic red soil of southern China
}

\author{
Huifeng Liu ${ }^{\text {a, b }}$, Xing Wu ${ }^{\text {a, c, * }, \text { Qing Wang }}{ }^{\text {a, b }}$, Shuai Wang ${ }^{\text {a, c }}$, Dan Liu ${ }^{\text {a, b }}$, \\ Guohua Liu ${ }^{\text {a, c, ** }}$ \\ a State Key Laboratory of Urban and Regional Ecology, Research Center for Eco-Environmental Sciences, Chinese Academy of Sciences, Beijing 100085, China \\ ${ }^{\mathrm{b}}$ University of Chinese Academy of Science, Beijing 100049, China \\ ' Joint Center for Global Change Studies, Beijing 100875, China
}

\section{A R T I C L E I N F O}

\section{Article history:}

Received 3 September 2016

Received in revised form

9 May 2017

Accepted 15 May 2017

Available online 23 May 2017

Handling Editor: Prof. C.C. Tebbe

\section{Keywords:}

Ammonia oxidation

Ammonia-oxidizing archaea

Ammonia-oxidizing bacteria

Fertilization

Land-use conversion

Red soil

\begin{abstract}
A B S T R A C T
Ammonia oxidation, the conversion of ammonium $\left(\mathrm{NH}_{4}^{+}-\mathrm{N}\right)$ to nitrite $\left(\mathrm{NO}_{2}^{-}-\mathrm{N}\right)$, is the critical step of nitrification and performed by ammonia-oxidizing archaea (AOA) and bacteria (AOB). However, the effects of land-use conversion and fertilization on the $A O A$ and $A O B$ are not well documented, and the contribution of these two groups to soil ammonia oxidation is still debatable. This study aimed to explore how land-use conversion from rice paddies (RP) to citrus orchards (OR) and fertilization affect the abundance and communities of $\mathrm{AOA}$ and $\mathrm{AOB}$, and whether $\mathrm{AOA}$ and $\mathrm{AOB}$ were correlated to ammonia oxidation. The potential ammonia oxidation $(\mathrm{PAO})$ was measured by chlorate inhibition method, and the abundance and communities of $\mathrm{AOA}$ and $\mathrm{AOB}$ were quantified using quantitative real-time polymerase chain reaction (qPCR), terminal restriction fragment length polymorphism (T-RFLP) and cloning and sequence analysis. Land-use conversion from RP to OR tended to increase PAO, whereas fertilization increased PAO only in the OR. qPCR results demonstrated that land-use conversion significantly increased AOA abundance, but failed to affect the AOB abundance. The AOA abundance was increased in the OR but decreased in the RP after fertilization, whereas fertilization distinctly stimulated AOB abundance in the OR and RP. T-RFLP analysis showed that the communities of AOA and AOB were significantly changed after land-use conversion. Meanwhile, fertilization significantly affected the communities of AOB both in the OR and RP and only affected the communities of AOA in the OR. Phylogenetic analyses of amoA genes showed that group 1.1 a like lineage predominated archaea ammonia oxidizers in the acidic red soil, while all AOB clones were belonged to the Nitrosospira. Besides, soil ammonia oxidation was positively correlated to AOA and AOB abundance both in the OR and RP. Our findings imply that land-use conversion and fertilization could potentially alter the ammonia oxidation by regulating the growth of AOA and AOB in this acidic red soil.
\end{abstract}

(c) 2017 Elsevier Masson SAS. All rights reserved.

\section{Introduction}

Ammonia oxidation, the conversion of ammonia $\left(\mathrm{NH}_{3}\right)$ to nitrite

\footnotetext{
* Corresponding author. State Key Laboratory of Urban and Regional Ecology, Research Center for Eco-Environmental Sciences, Chinese Academy of Sciences, Beijing 100085, China.

** Corresponding author. State Key Laboratory of Urban and Regional Ecology, Research Center for Eco-Environmental Sciences, Chinese Academy of Sciences, Beijing 100085, China.

E-mail addresses: xingwu@rcees.ac.cn (X. Wu), ghliu@rcees.ac.cn (G. Liu).
}

$\left(\mathrm{NO}_{2}-\right)$, is the first and rate-limiting step of nitrification and plays an important role in global nitrogen cycle [1]. Ammonia oxidation has important agricultural and environmental consequences, such as the availability of nitrogen, nitrate $\left(\mathrm{NO}_{3}^{-}-\mathrm{N}\right)$ leaching to groundwater and the releases of nitrous oxide [2]. Therefore, this step has been considered to be "pinhole" of nitrogen turnover and is an important process to be studied in different ecosystems.

It has long been accepted that ammonia oxidation is performed by autotrophic ammonia oxidizing bacteria (AOB) of the $\beta$ - and $\gamma$ subgroups of Proteobacteria [1,3]. This viewpoint has been rapidly changed by the discovery of new archaeal groups in the AOA strain, 
which also possess the homologs of AOB-like ammonia monooxygenase gene [4,5], thus raising the prospect of the existence of AOA in different ecosystems [6,7]. Though it has been widely assumed that ammonia oxidation is typically performed by the ammonia-oxidizers [6,8], our knowledge of the relative contribution of $A O A$ and $A O B$ in ammonia oxidation is still limited and inconsistent $[9,10]$. In fact, quantification of the amoA gene showed that AOA copy numbers were found to be more abundant than $\mathrm{AOB}$ in different ecosystems, supporting a possibly major contribution for AOA than AOB to ammonia oxidation, in particular in acidic soils or low-ammonia soils $[3,11,12]$. However, extensive previous studies showed that most of the ammonia oxidization was predominated by autotrophic AOB in nitrogen-rich soils [13-15]. In addition, though the huge phylogenetic members, which were found in the AOA and AOB, only specific groups could transform $\mathrm{NH}_{3}$ to $\mathrm{NO}_{2}{ }^{-}$[16]. Therefore, there is necessary to improve our understanding of the relative roles of $\mathrm{AOA}$ and $\mathrm{AOB}$ in the ammonia oxidation process.

Generally, abundance and communities of ammonia-oxizing communities vary with land-uses, fertilization and soil microconditions $[17,18]$. AOA and AOB have been found to co-exist in most agriculture soils and might be controlled by soil characteristics (e.g. soil moisture, $\mathrm{pH}$ and $\mathrm{NH}_{3}$ ) [19-22]. In the microcosm studies, the soil moisture might distinctly alter the communities of $\mathrm{AOA}$ and $\mathrm{AOB}[22,23]$. Meanwhile, higher ammonia oxidation rates were found in the dry period than the wet period [24,25]. Moreover, soil $\mathrm{pH}$ was known to be a main factor determining the activity and communities of soil AOA and AOB [26-28]. Some AOA and $A O B$ phylogeny have been found to be related to soil $\mathrm{pH}$, with increases in the ratio of amoA transcript/abundance accompanied by decreasing and increasing $\mathrm{pH}$ for $\mathrm{AOA}$ and $\mathrm{AOB}$ compositions, respectively [26]. In addition, ammonia $\left(\mathrm{NH}_{3}\right)$ provide energy sources for ammonia oxidizers and might influence the abundance of AOA and AOB [14,29]. Land use conversion from rice paddies to citrus orchards represented niche specialization with environmental factors (e.g. soil moisture, ammonia, pH, et al.,) that are key factors influencing AOA and AOB [30-32]. Moreover, such conversion would be definitely affected the ammonia oxidation rates. However, very little is known about how soil ammonia oxidizers and ammonia oxidation rates might respond to the conversion from rice paddies to citrus orchards.

Fertilization is one of the most common agronomic practices for rice paddies and orchards throughout the world. Generally, nitrogen fertilization may change $\mathrm{NH}_{3}$ availability and thereby affect ammonia oxidizers and regulate the ammonia oxidation in soil [10,33]. Moreover, nitrogen inputs into soils are generally accompanied by a decrease in soil $\mathrm{pH}$, which tend to have contradictory effects on the abundance and activity of AOA and AOB [10]. Therefore, differences in physiology and metabolic pathways imply that the responses of $A O A$ and $A O B$ to the change of soil properties induced by fertilization are different [34]. For example, long-term fertilization was shown to significantly affect AOB abundance, but not for AOA in the alkaline soil [14,35]. In contrast, previous findings have also reported that fertilization could increase the abundance of $A O A$, but has minor impact on $A O B$ in the acidic soils $[36,37]$. It has also been suggested that fertilization could affect the soil ammonia oxidation rates by affecting the ammonia oxidizers $[25,29]$. As a result, it is necessary to obtain an understanding of how fertilization affects the abundance and communities of AOA and $\mathrm{AOB}$ and the ammonia oxidation rates.

Over the past few years, the acidic red soil regions have undergone great changes in land-uses, especially the conversion of rice paddies to upland cultivations for growing vegetables, fruits and economic forest due to the increasing market demands and higher economic returns. This has resulted in a diverse range of land-uses with different cultivation, irrigation and fertilizer rate, which in turn could cause significant changes in soil ammonia oxidizers with different abundance, compositions and activities. However, litter study is available on the responses of soil ammonia oxidation and ammonia oxidizers to land-use conversion and fertilization in this acidic red soil of southern China. Therefore, the present study aimed to (1) evaluate the effects of land-use conversion and fertilization on soil potential ammonia oxidation rates (PAO); (2) assess the relative changes in the abundance and compositions of $A O A$ and $A O B$; and (3) explore the relationships between the PAO and AOA and AOB. We hypothesized that (1) the PAO would be increased after the land-use conversion from rice paddies to orchards and fertilization; (2) land-use conversion and fertilization would alter the abundance and compositions of AOA and $\mathrm{AOB}$; and (3) changes in abundance and compositions of AOA and AOB are intimately related to soil PAO.

\section{Material and methods}

\subsection{Field site and soil sampling}

The study fields were conducted in the Qianyanzhou Ecological Research Station of Chinese Academy of Sciences $\left(26^{\circ} 44^{\prime} 46^{\prime \prime} \mathrm{N}\right.$, $115^{\circ} 04^{\prime} 05^{\prime \prime}$ E) of Jiangxi province, southern China. The experimental site is a subtropical monsoon climate with an average annual air temperature and precipitation of $17.9^{\circ} \mathrm{C}$ and $1489.0 \mathrm{~mm}$, respectively. Double cropping of rice is one of the important cropping systems in the region. The soils in this area are sandy loam and classified as Cambosols (Ultisols classification).

The two common land-use types (i.e. rice paddy and citrus orchard) were used for the present study. The experimental site was cultivated with rice paddies for more than 10 years and had been converted to citrus orchards in June 2012. Each land-use had two fertilization treatments: conventional fertilization and nonfertilization. Then, four treatments were included, referred as, citrus orchards with fertilization (OR-F) and without fertilization (OR$\mathrm{NF}$ ), and rice paddies with fertilization (RP-F) and without fertilization (RP-NF). All treatments were arranged in a randomized block design with four replications, totaling 16 plots. Each plot was $168 \mathrm{~m}^{2}$ and was isolated by a buffer strip (12 m length and $2 \mathrm{~m}$ width). In the OR-F, compound fertilizer and urea were applied, whereas in the RP-F, compound fertilizer was applied as basal fertilization during the transplanting and urea was applied at the tillering stage. In order to ensure survival and yield, a floodwater layer of 5-7 cm in depth was maintained in the RP till to the midseason drainage, which began from April 18 and ended on June 10, 2014 for the early rice. Details about descriptions of the experimental site and planting density were recorded in our former studies [38].

Soil samples were collected at four times representing a paddy cycle: T1 = April 28, transplantation and water logging for RP and fertilizer applied for OR-F and RP-F; T2 = May 13, fertilizer applied for RP-F and water logging for RP; T3 = June 24, drainage and precrop; T4 = July 23, harvest. For each time point, samples comprised 5 cores (diameter $=3 \mathrm{~cm}$ ) from the top layer $(0-10 \mathrm{~cm})$ were acquired, pooled together, passed through a $2 \mathrm{~mm}$ sieve, and any visible material was removed. Thus, 64 soil samples were collected. Subsequently, subsamples of each soil sample were stored at $4{ }^{\circ} \mathrm{C}$ for analyses of soil properties or at $-80^{\circ} \mathrm{C}$ for molecular analysis. The details of the cultivation, fertilization schemes and time points of sampling are presented in Table 1.

\subsection{Soil chemical analyses}

The soil pH was measured by suspending $8 \mathrm{~g}$ of dry soils in $20 \mathrm{ml}$ 
Table 1

Management practices and the sampling time in the study fields.

\begin{tabular}{|c|c|c|}
\hline Land-use & Management and sampling time & Date \\
\hline \multirow[t]{5}{*}{ Citrus orchards } & Compound fertilizer $\left(67.2 \mathrm{~kg} \mathrm{~N} \mathrm{ha}^{-1}\right)$ and urea $\left(20.8 \mathrm{~kg} \mathrm{~N} \mathrm{ha}^{-1}\right)$ was applied to OR-F & April 17, 2014 \\
\hline & Time points of sampling (T1) & April 28, 2014 \\
\hline & Time points of sampling (T2) & May 13, 2014 \\
\hline & Time points of sampling (T3) & June 24,2014 \\
\hline & Time points of sampling (T4) & July 23, 2014 \\
\hline \multirow[t]{9}{*}{ Rice paddies } & Flooding & April 26, 2014 \\
\hline & Rice transplanting, and compound fertilizer $\left(72 \mathrm{~kg} \mathrm{~N} \mathrm{ha}^{-1}\right)$ was applied to the RP-F & April 27, 2014 \\
\hline & Time points of sampling (T1) & April 28, 2014 \\
\hline & Urea (106 kg N ha ${ }^{-1}$ ) were applied to the fertilized fields & May 7, 2014 \\
\hline & Time points of sampling (T2) & May 13, 2014 \\
\hline & Drainage & June 10, 2014 \\
\hline & Time points of sampling (T3) & June 24,2014 \\
\hline & Rice harvest & July 22, 2014 \\
\hline & Time points of sampling (T4) & July 23, 2014 \\
\hline
\end{tabular}

of distilled water. Soil organic carbon (SOC), total nitrogen (TN) and the ratio of $\mathrm{C}: \mathrm{N}$ were measured by an element analyzer (Elementar, Hanau, Germany). Soil $\mathrm{NH}_{4}^{-}-\mathrm{N}$ and $\mathrm{NO}_{3}^{-}-\mathrm{N}$ contents were extracted by suspending $20 \mathrm{~g}$ of fresh soil in $100 \mathrm{ml}$ of $1 \mathrm{M} \mathrm{KCl}$ and determined with the continuous-flow auto analyzer (Seal AA3, Norderstedt, Germany).

\subsection{Soil potential ammonia oxidation rates (PAO)}

Soil PAO was determined as accumulated nitrite using the chlorate inhibition method [39]. Briefly, each fresh soil sample $(5.0 \mathrm{~g})$ was transferred to $50 \mathrm{ml}$ centrifuge tubes including $20 \mathrm{ml}$ of phosphate buffer solution (PBS) $\left(\mathrm{g} \mathrm{l}^{-1}\right) \mathrm{NaCl}, 8.0 ; \mathrm{KCl}, 0.2 ; \mathrm{Na}_{2} \mathrm{HPO}_{4}$, 0.2 ; and $\mathrm{KH}_{2} \mathrm{PO}_{4}, 0.2$; $\mathrm{pH} 7.4$ with $1 \mathrm{mM}\left(\mathrm{NH}_{4}\right)_{2} \mathrm{SO}_{4}$. After that, $50 \mathrm{mg} \mathrm{l}^{-1} \mathrm{KClO}_{3}$ was added to the tubes to restrain nitrite oxidation, and the suspension was incubated in a dark incubator at $25^{\circ} \mathrm{C}$ for $24 \mathrm{~h}$. Subsequently, nitrite was extracted using $5 \mathrm{ml}$ of $2 \mathrm{M} \mathrm{KCl}$ and assayed using a spectrophotometer at a wavelength of $540 \mathrm{~nm}$ with $N$-(1-naphthyl) ethylenediamine dihydrochloride.

\subsection{Soil DNA extraction and quantitative real-time polymerase chain reaction $(q P C R)$ of amoA genes}

According to the manufacturer's protocol, the total soil genomic DNA was extracted from $0.3 \mathrm{~g}$ of freeze-dried soil sample with Mobio PowersoilTM DNA isolation kit (MoBio Laboratories Inc, Carlsbad, CA, USA). The concentrations and qualities of the DNA were measured using an Nanodrop ND-1000 spectrophotometer (NanoDrop Technologies, Wilmington, DE, USA). All the soil DNA were fivefold diluted with nuclease-free water to reduce potential PCR inhibition and stored at $-80^{\circ} \mathrm{C}$ for further use.

qPCR was used to determine the abundance of AOA (primer set as CrenamoA23F (ATGGTCTGGCTWAGACG)/CrenamoA616R (GCCATCCATCTGTATGTCCA)) and AOB (primer set as amoA1F (GGGGTTTCTACTGGTGGT)/amoA2R(CCCCTCKGSAAAGCCTTCTTC)). The qPCR assays were carried out on an iCycler IQ2 Thermocycler (Bio-Rad Laboratories, Hercules, CA, USA). Amplification was performed using a $25 \mu \mathrm{l}$ reaction mixture containing $12.5 \mu \mathrm{l}$ of $\mathrm{SYBR}^{\circledR}$ Premix Ex Taq ${ }^{\mathrm{TM}}$ (TaKaRa Biotechnology, Dalian, China), $0.5 \mu \mathrm{l}$ of bovine serum albumin $\left(20 \mathrm{mg} \mathrm{ml}^{-1}\right), 0.5 \mu \mathrm{l}$ of each primer $(10 \mu \mathrm{M})$, $2 \mu \mathrm{l}$ of fivefold-diluted DNA (1-10 ng) and $9 \mu \mathrm{l}$ of nuclease-free water. The detailed preparation of plasmid DNA was the same as He et al. [37]. Briefly, standards plasmid DNA used in the qPCR were prepared by cloning amoA from genomic DNA from Nitrosospira multiformis and Nitrosomonas europaea using a MiniBEST Plasmid Purification Kit (TaKaRa), with concentrations being quantified with a NanoDrop ND-1000 Spectrophotometer. A 10-fold dilution series of the plasmid DNA was prepared to generate a standard curve covering seven orders of magnitude from $10^{2}$ to $10^{8}$ copies of template per assay $\left(\mathrm{R}^{2}>0.98\right)$. The PCR condition for AOA and AOB genes were as followings: $95^{\circ} \mathrm{C}$ for $5 \mathrm{~min}, 35$ cycles of $95^{\circ} \mathrm{C}$ for $45 \mathrm{~s}$, $53{ }^{\circ} \mathrm{C}$ for $42 \mathrm{~s}, 72{ }^{\circ} \mathrm{C}$ for $60 \mathrm{~s}$, a final elongation step of $5 \mathrm{~min}$ at $72{ }^{\circ} \mathrm{C}$, and a data collection of $83^{\circ} \mathrm{C}$ for $15 \mathrm{~s}$. The qPCR was performed in triplicate, with amplification efficiencies of 90\%-95\%. Besides, product specificity was examined by melt curve analysis at the end of the PCR amplication and visualized by agarose gel electrophoresis. The final quantities of $\mathrm{AOA}$ and $\mathrm{AOB}$ were acquired by calibrating against the extracted total DNA concentration.

\subsection{Terminal restriction fragment length polymorphism (TRFLP), cloning and sequencing analysis}

The compositions of $\mathrm{AOA}$ and $\mathrm{AOB}$ were analyzed with terminal restriction fragment length polymorphism (TRFLP) using soil samples collected in July 2014. Specifically, PCR amplification was performed with the FAM-labeled primer pairs as those used for qPCR. Meanwhile, the PCR amplification conditions were the same as described above. The PCR products obtained were purified with a PCR purification kit (Promega, San Luis Obispo, CA, USA). After that, the fluorescent-labeled PCR products (100 ng) were digested with the restriction enzymes Hhal and MspI for the AOA and AOB genes, respectively, at $37^{\circ} \mathrm{C}$ for $3 \mathrm{~h}$, and inactivated at $65^{\circ} \mathrm{C}$ for $20 \mathrm{~min}$. The enzymes were selected based on in silico restriction analysis of 50 amoA sequences from $\mathrm{AOA}$ and $\mathrm{AOB}$ respectively. The digests were purified by ethanol precipitation and resuspended in $20 \mu \mathrm{l}$ of water. Then, $10 \mu \mathrm{l}$ of the samples were mixed with $15 \mu \mathrm{l}$ of formamide and $0.3 \mu \mathrm{l}$ of the LIZ-labeled internal DNA fragment length standard $(500 \mathrm{bp})$. Fragment size analysis was determined using an ABI 3730xl DNA analyzer (Applied Biosystems, Warrington, United Kingdom). The peak heights were analyzed with the GeneMarker software package (version 2.2.0). The T-RFs with a relative abundance more than $1 \%$ and fragment lengths higher than 50 bp were employed for further analysis.

Clone libraries of AOA and AOB were constructed from the RPNF. PCR amplifications were performed with the primer pairs as the qPCR. The purified PCR products were ligated into the pGEM-T Easy Vector (Promega, USA) and then transformed into E. coli JM109 (Takara Biotechnology, Japan). A total of 50 clones, respectively for $\mathrm{AOA}$ and $\mathrm{AOB}$, were randomly selected and sequenced. The obtained sequences were subjected to homology analysis with QIIME and sequences showing more than $96 \%$ identity to each other were classified into the same operational taxonomic units (OTUs). The representative sequences were aligned with BLAST similarity search program to find the most similar sequences from the 
GenBank database. The representative sequences and the most similar sequences were used for constructing the phylogenetic trees. The phylogenetic analysis was conducted using MEGA 5.0, and neighbor-joining trees were constructed by performing 1000 replicates to generate bootstrap values. The sequences used in our analysis were submitted to the GenBank database under the accession numbers: KY624317-KY624330 for the AOA and KY624331-KY624346 for the AOB, respectively.

\subsection{Statistical analysis}

Repeated measures analysis of variance (ANOVA) was applied to examine the differences of soil properties, PAO and abundance of AOA and AOB among the four treatments $(P<0.05)$. Experimental treatments were set as between-subject factors, and measurement date was selected as a within-subject variable. Regression analyses were employed to examine the relationships among PAO, abundance of AOA and AOB, and soil characteristics. All the statistical analyses were performed with the SPSS software (SPSS Inc., Chicago, IL, USA). Redundancy analysis (RDA) was performed to provide a visual map of the relationships between compositions of AOA and $\mathrm{AOB}$, and soil properties, and was performed using the R ( R Development Core Team, 2009).

\section{Results}

\subsection{Soil properties}

Soil TN, C:N and pH across four treatments showed no obvious seasonality $(P>0.05)$, whereas SOC, $\mathrm{NH}_{4}^{+}-\mathrm{N}$ and $\mathrm{NO}_{3}^{-}-\mathrm{N}$ showed a pattern of seasonal variations $(P<0.05)$ (Table 2 , Table 3$)$. Land-use conversion significantly increased soil TN contents $(P<0.05)$, failed to affect SOC contents and C:N $(P>0.05)$ (Table 2, Table 3). Fertilization significantly affected SOC contents $(P<0.05)$, had no significant effect on TN contents and C:N $(P>0.05)$ (Table 2, Table 3$)$. Land-use conversion and fertilization significantly reduced soil $\mathrm{pH}$ $(P<0.05)$, and the $\mathrm{pH}$ of the four treatments followed the order of OR-F $<$ OR-NF $<$ RP-F $<$ RP-NF (Table 2, Table 3). Land-use conversion significantly increased soil $\mathrm{NO}_{3}^{-}-\mathrm{N}$ content $(P<0.05)$, but failed to affect soil $\mathrm{NH}_{4}^{+}-\mathrm{N}$ content $(P>0.05)$ (Table 2, Table 3). However, the $\mathrm{NH}_{4}^{+}-\mathrm{N}$ and $\mathrm{NO}_{3}^{-}-\mathrm{N}$ concentrations in the OR-F and RP-F were significantly higher, when compared with those in the OR-NF and RP-NF in the four sampling times $(P<0.05)$ (Table 2$)$.

\subsection{Soil potential ammonia oxidization rates (PAO)}

Soil PAO showed significant seasonal variations during the early rice season (Fig. 1a). In the OR, the highest PAO were observed in OR-F in May, which was almost 36 days after fertilization. In the RP, the higher PAO were observed in June and July (Fig. 1a), showing that drainage in rice paddies would trigger higher ammonia oxidation. The difference in the PAO exhibited the following order: OR-F > OR-NF > RP-F = RP-NF (Table 4). Irrespective of the fertilization treatment, the PAO was distinctly higher in the OR in comparison with that in the RP (Table 4). However, in the OR, fertilization increased the PAO, whereas in the RP, fertilization did not significantly affect the PAO (Table 4). Land-use conversion $(P<0.001)$, fertilization $(P=0.001)$, as well as their interactive effects $(P=0.017)$ had a significant influence on the PAO (Table 5).

\subsection{Abundance of $A O A$ and $A O B$}

The copy numbers of the AOA amoA genes in the OR (varying from $2.19 \times 10^{7}$ to $3.44 \times 10^{8}$ copies $g^{-1}$ dry soil) were significantly greater, when compared with that in the RP (varying from $0.91 \times 10^{7}$ to $1.91 \times 10^{8}$ copies $g^{-1}$ dry soil) (Fig. 1 b). In the OR, maximum copy numbers of AOA were observed in May, whereas in the RP, soil AOA abundance showed no significant seasonal variations and the maximum AOA abundance were detected in April (Fig. 1b). Thus, land-use conversion significantly increased the AOA abundance $(P<0.001)$ (Table 4 , Table 5$)$. The contrasting effects of fertilization on soil AOA abundance were observed in the OR and RP, with OR-F exhibiting higher AOA abundance than OR-NF; however, the AOA abundance in RP-F was lower, when compared with that in RP-NF (Table 4). Moreover, there was a significant interactive effect of land-use conversion and fertilization on AOA abundance $(P<0.001)$ (Table 5$)$.

The abundance of the amoA AOB genes ranged from $1.38 \times 10^{6}$ to $1.59 \times 10^{7}$ copies $g^{-1}$ dry soil in the OR and from $1.40 \times 10^{6}$ to $9.15 \times 10^{6}$ copies $^{-1}$ dry soil in the RP (Fig. 1c). In general, the copy numbers of AOB displayed an increasing trend during our observation period and peaked in July both in the OR and RP (Fig. 1c). In contrast to AOA abundance, no significant difference in the AOB was observed in response to land-use conversion $(P>0.05)$ (Table 5). In addition, the abundances of AOB in the OR-F and RP-F were significantly higher, when compared with those in the OR-NF and RP-NF, respectively (Table 4). Moreover, land-use conversion, fertilization as well as their interactions significantly affect the ratio of AOA/AOB $(P<0.05)$, and the lowest AOA/AOB were observed in

Table 2

Soil properties for the treatments and sampling times. Numbers suggest means of four replicates, and numbers in the parentheses are standard errors.

\begin{tabular}{|c|c|c|c|c|c|c|c|}
\hline Treatment & Time & $\begin{array}{l}\text { SOC } \\
\left(\mathrm{g} \mathrm{kg}^{-1}\right)\end{array}$ & $\begin{array}{l}\mathrm{TN} \\
\left(\mathrm{g} \mathrm{kg}^{-1}\right)\end{array}$ & $\mathrm{C}: \mathrm{N}$ & $\mathrm{pH}$ & $\begin{array}{l}\mathrm{NH}_{4}^{+}-\mathrm{N} \\
\left(\mathrm{mg} \mathrm{kg}^{-1}\right)\end{array}$ & $\begin{array}{l}\mathrm{NO}_{3}^{-}-\mathrm{N} \\
\left(\mathrm{mg} \mathrm{kg}^{-1}\right)\end{array}$ \\
\hline \multirow[t]{4}{*}{ OR-F } & $\mathrm{T} 1$ & $10.17(0.25)$ & $1.14(0.03)$ & $8.94(0.12)$ & $4.89(0.04)$ & $7.19(0.84)$ & $6.28(0.39)$ \\
\hline & $\mathrm{T} 2$ & $9.51(0.34)$ & $1.10(0.04)$ & $8.66(0.02)$ & $4.68(0.04)$ & $15.07(1.08)$ & $1.78(0.23)$ \\
\hline & T3 & $10.71(0.80)$ & $1.43(0.26)$ & $9.21(0.09)$ & $5.06(0.01)$ & $10.59(1.21)$ & $4.91(0.17)$ \\
\hline & $\mathrm{T} 4$ & $9.14(0.49)$ & $1.05(0.05)$ & $8.68(0.12)$ & $4.93(0.01)$ & $10.18(0.94)$ & $2.96(0.18)$ \\
\hline \multirow[t]{4}{*}{ OR-NF } & $\mathrm{T} 1$ & $9.92(0.43)$ & $1.12(0.05)$ & $8.85(0.02)$ & $5.00(0.03)$ & $5.24(0.38)$ & $3.23(0.36)$ \\
\hline & $\mathrm{T} 2$ & $9.05(0.31)$ & $1.05(0.05)$ & $8.62(0.08)$ & $5.01(0.02)$ & $10.91(0.39)$ & $1.48(0.14)$ \\
\hline & T3 & $9.86(0.43)$ & $1.11(0.05)$ & $8.91(0.06)$ & $5.13(0.01)$ & $8.07(0.30)$ & $2.78(0.44)$ \\
\hline & $\mathrm{T} 4$ & $9.25(0.62)$ & $1.07(0.07)$ & $8.65(0.13)$ & $4.97(0.02)$ & $8.48(0.23)$ & $1.79(0.14)$ \\
\hline \multirow[t]{4}{*}{ RP-F } & $\mathrm{T} 1$ & $9.24(0.40)$ & $1.09(0.05)$ & $8.47(0.06)$ & $5.01(0.03)$ & $8.58(0.20)$ & $1.62(0.10)$ \\
\hline & $\mathrm{T} 2$ & $9.28(0.36)$ & $1.03(0.04)$ & $8.06(0.06)$ & $5.20(0.04)$ & $14.53(0.38)$ & $0.58(0.11)$ \\
\hline & T3 & $9.47(0.06)$ & $1.07(0.01)$ & $8.88(0.08)$ & $5.24(0.05)$ & $13.09(0.47)$ & $2.04(0.36)$ \\
\hline & $\mathrm{T} 4$ & $8.52(0.19)$ & $1.01(0.02)$ & $8.41(0.14)$ & $5.07(0.02)$ & $12.09(0.68)$ & $0.65(0.03)$ \\
\hline \multirow[t]{4}{*}{ RP-F } & $\mathrm{T} 1$ & $8.95(0.21)$ & $1.01(0.05)$ & $8.60(0.08)$ & $5.28(0.04)$ & $4.59(0.06)$ & $1.59(0.19)$ \\
\hline & $\mathrm{T} 2$ & $8.27(0.16)$ & $1.12(0.02)$ & $8.27(0.07)$ & $5.28(0.02)$ & $11.16(0.44)$ & $0.56(0.07)$ \\
\hline & T3 & $8.98(0.41)$ & $1.06(0.01)$ & $8.80(0.30)$ & $5.32(0.05)$ & $7.43(0.56)$ & $0.69(0.12)$ \\
\hline & $\mathrm{T} 4$ & $8.21(0.26)$ & $0.96(0.02)$ & $8.36(0.08)$ & $5.09(0.01)$ & $6.98(0.48)$ & $0.48(0.09)$ \\
\hline
\end{tabular}


Table 3

Results of repeated measures ANOVA on the effects of land-use conversion, fertilization, date, and their interaction on soil properties.

\begin{tabular}{|c|c|c|c|c|c|c|c|c|c|c|c|c|}
\hline \multirow[t]{2}{*}{ Source of variation } & \multicolumn{2}{|l|}{ SOC } & \multicolumn{2}{|l|}{$\mathrm{TN}$} & \multicolumn{2}{|l|}{$\mathrm{C}: \mathrm{N}$} & \multicolumn{2}{|l|}{$\mathrm{pH}$} & \multicolumn{2}{|l|}{$\mathrm{NH}_{4}^{+}-\mathrm{N}$} & \multicolumn{2}{|l|}{$\mathrm{NO}_{3}^{-}-\mathrm{N}$} \\
\hline & $F$ & $P$ & $F$ & $P$ & $F$ & $P$ & $F$ & $P$ & $F$ & $P$ & $F$ & $P$ \\
\hline \multicolumn{13}{|l|}{ Between subjects } \\
\hline Land-use conversion & 0.47 & 0.505 & 5.02 & 0.045 & 1.15 & 0.305 & 210.55 & $<0.001$ & 0.543 & 0.475 & 276.17 & $<0.001$ \\
\hline Fertilization & 8.67 & 0.012 & 1.70 & 0.216 & 0.48 & 0.500 & 50.22 & $<0.001$ & 185.75 & $<0.001$ & 128.31 & $<0.001$ \\
\hline $\begin{array}{l}\text { Land-use conversion } \times \text { Fertilization } \\
\text { Within subjects }\end{array}$ & 0.35 & 0.566 & 0.31 & 1.120 & 0.09 & 0.773 & 2.07 & 0.176 & 1.07 & 0.322 & 31.78 & $<0.001$ \\
\hline Date & 7.50 & 0.018 & 1.00 & 0.337 & 1.61 & 0.23 & 0.012 & 0.916 & 5.70 & 0.034 & 58.76 & $<0.001$ \\
\hline Date $\times$ Land-use conversion & 0.186 & 0.694 & 0.78 & 0.395 & 0.89 & 0.774 & 23.81 & $<0.001$ & 0.39 & 0.541 & 10.16 & 0.008 \\
\hline Date $\times$ Fertilization & 0.369 & 0.555 & 0.23 & 0.642 & 0.32 & 0.58 & 23.81 & $<0.001$ & 0.09 & 0.772 & 1.63 & 0.23 \\
\hline Date $\times$ Land-use conversion $\times$ Fertilization & 1.271 & 0.282 & 0.15 & 0.706 & 2.45 & 0.14 & 0.001 & 0.972 & 0.125 & 0.730 & 21.69 & 0.001 \\
\hline
\end{tabular}
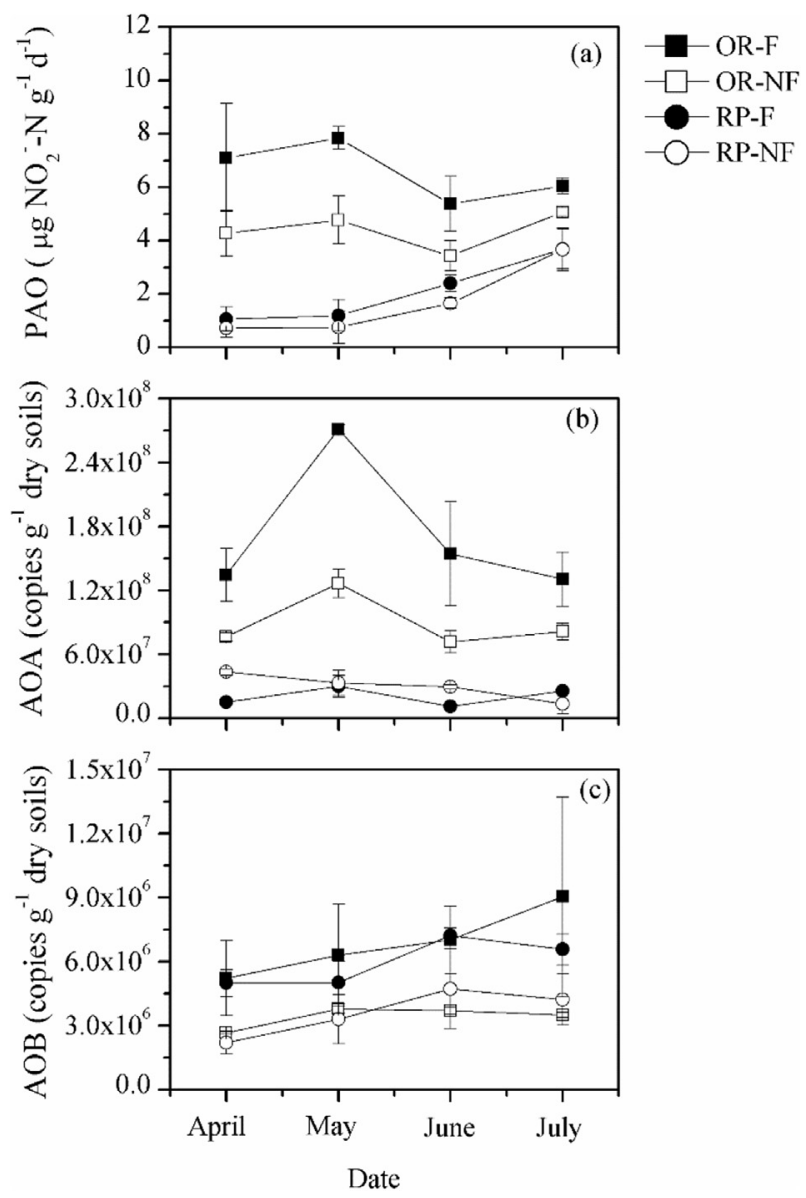

Fig. 1. Dynamics of soil PAO (a), AOA abundance (b), and AOB abundance (c) in the four treatments. The data are means with standard errors. the RP-F (Table 4, Table 5). Overall, the AOA abundance was greater than the AOB gene abundance in the four treatments.

\subsection{Community compositions of $A O A$ and $A O B$}

In total, five T-RFs were considered to be the main peaks in the TRFLP analysis of amoA AOA and amoA AOB gene (Fig. 2 a,b). In the AOA, T-RF 255 bp was only detected in the OR, but not in the RP, TRF 540 bp showed the highest relative abundance (Fig. 2a). The response of the compositions of $\mathrm{AOA}$ and $\mathrm{AOB}$ to land-use conversion and fertilization, and the main factors affecting them were investigated by RDA analysis (Fig. 3a). The different cluster of symbols suggested that land-use conversion significantly affect the compositions of AOA, whereas fertilization could only affect the AOA compositions in the RP. However, both land-use conversion and fertilization could distinctly shape the compositions of the AOB (Fig. 3b). Meanwhile, the strength of each variable suggested that $\mathrm{pH}$ and soil $\mathrm{NO}_{3}^{-}-\mathrm{N}$ were the main factors in shaping the compositions of AOA (Fig. 3a), whereas soil $\mathrm{NH}_{4}^{+}-\mathrm{N}$ was an important factor influencing the $A O B$ compositions (Fig. $3 \mathrm{~b}$ ). In the AOA compositions, T-RFs of 255 bp and 347 bp were more related to soil $\mathrm{pH}, \mathrm{T}-\mathrm{RFs}$ of $218 \mathrm{bp}$ and 540 bp were correlated to soil $\mathrm{NO}_{3}^{-}-\mathrm{N}$ contents, and T-RF of 163 bp was more related to soil $\mathrm{NH}_{4}^{+}-\mathrm{N}$ (Fig. 3a). In the AOB compositions, T-RFs of 59 bp and 103 bp were, respectively related to soil $\mathrm{NH}_{4}^{+}-\mathrm{N}$ and soil $\mathrm{pH}$ (Fig. 3b). The RDA results also suggested that the PAO was more closely related to the T-RF of 218 bp retrieved from AOA (Fig. 3a).

The phylogenetic analysis of the amoA AOA genes revealed that T-RFs of $163 \mathrm{bp}, 218 \mathrm{bp}, 255 \mathrm{bp}$, and $347 \mathrm{bp}$ were specified to group $1.1 \mathrm{~b}$, whereas T-RF of $540 \mathrm{bp}$ was characteristic of group $1.1 \mathrm{a}$ (Fig. 4). Meanwhile, archaea amoA sequences affiliated with group 1.1 a were the most abundant members (Fig. 4). Cloning and sequencing analysis of amoA AOB genes suggested that the acquired T-RF of 59 bp was belonged to the Cluster 3C, Cluster 0\&2, Cluster 3b, and Cluster 3a, T-RF of 155 bp was ascribed to Cluster $0 \& 2$ and Cluster $3 \mathrm{~b}$ (Fig. 5). The remaining three T-RFs were belonged to a single lineage, i.e. T-RF of $232 \mathrm{bp}$ to Cluster 0\&2, T-RF of 103 to Cluster 3b, and T-RF of 254 to Cluster 3a (Fig. 5). All AOB clones fell within the Nitrosospira (Fig. 5).

Table 4

Average soil PAO, AOA abundance, $\mathrm{AOB}$ abundance, and $\mathrm{AOA} / \mathrm{AOB}$ ratio in the four treatments.

\begin{tabular}{|c|c|c|c|c|}
\hline & $\begin{array}{l}\text { Soil PAO } \\
\left(\mu \mathrm{NO}_{2}^{-}-\mathrm{N} \mathrm{g}^{-1} \mathrm{~d}^{-1}\right)\end{array}$ & $\begin{array}{l}\text { AOA abundance } \\
\text { (copies } \mathrm{g}^{-1} \text { dry soil) }\end{array}$ & $\begin{array}{l}\text { AOB abundance } \\
\text { (copies } \mathrm{g}^{-1} \text { dry soil) }\end{array}$ & $\mathrm{AOA} / \mathrm{AOB}$ \\
\hline OR-F & $6.41 \pm 0.92 \mathrm{a}$ & $1.41 \times 10^{8} \pm 1.42 \times 10^{7} \mathrm{a}$ & $6.59 \times 10^{6} \pm 1.90 \times 10^{6} \mathrm{a}$ & $24.4 \pm 1.80 a$ \\
\hline OR-NF & $4.51 \pm 1.01 b$ & $7.77 \times 10^{7} \pm 7.56 \times 10^{6} \mathrm{~b}$ & $3.41 \times 10^{6} \pm 1.65 \times 10^{5} \mathrm{~b}$ & $24.0 \pm 2.26 a$ \\
\hline RP-F & $2.08 \pm 0.53 c$ & $2.05 \times 10^{7} \pm 3.19 \times 10^{6} \mathrm{~d}$ & $5.95 \times 10^{6} \pm 6.76 \times 10^{5} \mathrm{a}$ & $3.89 \pm 0.17 b$ \\
\hline RP-NF & $1.69 \pm 0.49 c$ & $6.07 \times 10^{7} \pm 6.64 \times 10^{6} \mathrm{c}$ & $3.61 \times 10^{6} \pm 1.94 \times 10^{6} \mathrm{~b}$ & $19.2 \pm 2.63 a$ \\
\hline
\end{tabular}

Values are means with standard errors. Different letters in the same column suggest significant differences $(P<0.05)$. 
Table 5

Results of repeated measures ANOVA on the effects of land-use conversion, fertilization, date, and their interaction on soil PAO, AOA, AOB, and the AOA/AOB.

\begin{tabular}{|c|c|c|c|c|c|c|c|c|}
\hline \multirow[t]{2}{*}{ Source of variation } & \multicolumn{2}{|l|}{ PAO } & \multicolumn{2}{|l|}{$\mathrm{AOA}$} & \multicolumn{2}{|l|}{ AOB } & \multicolumn{2}{|c|}{ AOA/AOB } \\
\hline & $F$ & $P$ & $F$ & $P$ & $F$ & $P$ & $F$ & $P$ \\
\hline \multicolumn{9}{|l|}{ Between subjects } \\
\hline Land-use conversion & 209.77 & $<0.001$ & 203.99 & $<0.001$ & 0.345 & 0.568 & 45.589 & 0.000 \\
\hline Fertilization & 18.57 & 0.001 & 5.73 & 0.034 & 55.715 & $<0.001$ & 15.940 & 0.002 \\
\hline $\begin{array}{l}\text { Land-use conversion } \times \text { Fertilization } \\
\text { Within subjects }\end{array}$ & 7.67 & 0.017 & 115.56 & $<0.001$ & 1.27 & 0.281 & 17.887 & 0.001 \\
\hline Date & 25.61 & $<0.001$ & 0.273 & 0.611 & 71.26 & 0.000 & 18.294 & 0.000 \\
\hline Date $\times$ Land-use conversion & 16.14 & 0.002 & 38.73 & $<0.001$ & 1.39 & 0.26 & 11.874 & 0.000 \\
\hline Date $\times$ Fertilization & 1.83 & 0.201 & 18.53 & 0.001 & 3.21 & 0.098 & 3.885 & 0.017 \\
\hline Date $\times$ Land-use conversion $\times$ Fertilization & 1.090 & 0.32 & 0.83 & 0.38 & 4.698 & 0.051 & 1.372 & 0.267 \\
\hline
\end{tabular}
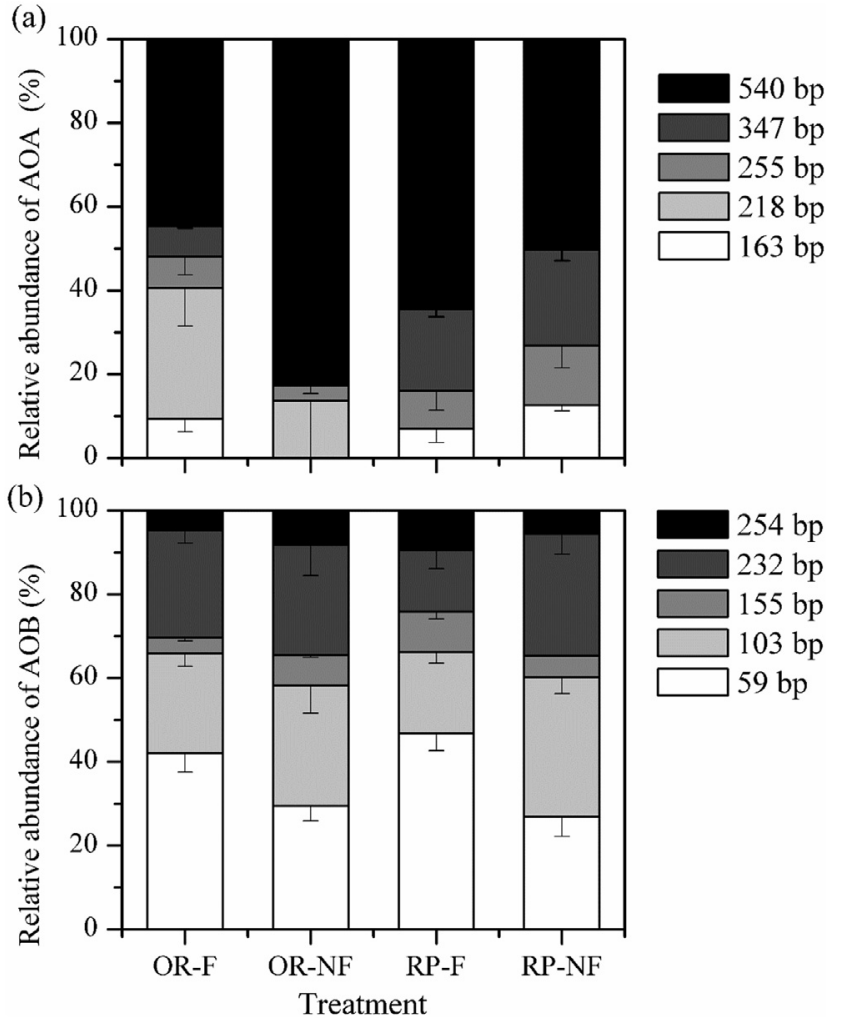

Fig. 2. Relative abundances of $T-R F s$ of $A O A$ amoA (a) and $A O B$ amoA (b) gene restricted by Hhal and MspI in the four treatments. The data are means with standard errors.

\subsection{Relationship among soil $P A O$, abundance of $A O A$ and $A O B$, soil} $\mathrm{pH}$ and $\mathrm{NH}_{4}^{+}-\mathrm{N}$ content

A weak correlation between soil AOA abundance and $\mathrm{pH}$ in the OR and significant positive relationships between soil AOA abundance and $\mathrm{pH}$ in the RP were found (Fig. 6a). However, no significant relationships were observed between soil AOB abundance and $\mathrm{pH}$ both in the OR and RP (Fig. 6b). The soil AOA abundance in the OR and RP was positively and negatively correlated to soil $\mathrm{NH}_{4}^{+}-\mathrm{N}$ content, respectively (Fig. 6c). In both $\mathrm{OR}$ and $\mathrm{RP}$, the soil AOB abundance was positively associated with $\mathrm{NH}_{4}^{+}-\mathrm{N}$ contents and the relationship well fitted the linear equations (Fig. 6d). A significant and negative relationship was detected between soil $\mathrm{PAO}$ and $\mathrm{pH}$ both in the OR and RP (Fig. 7a). In the OR, soil PAO was positively correlated to soil $\mathrm{NH}_{4}^{+}-\mathrm{N}$ content, whereas no significant correlations between these two factors were noted in the RP (Fig. 7b). The relationships between the $\mathrm{PAO}$ and $\mathrm{AOA}$ amoA and $\mathrm{AOB}$ amoA gene

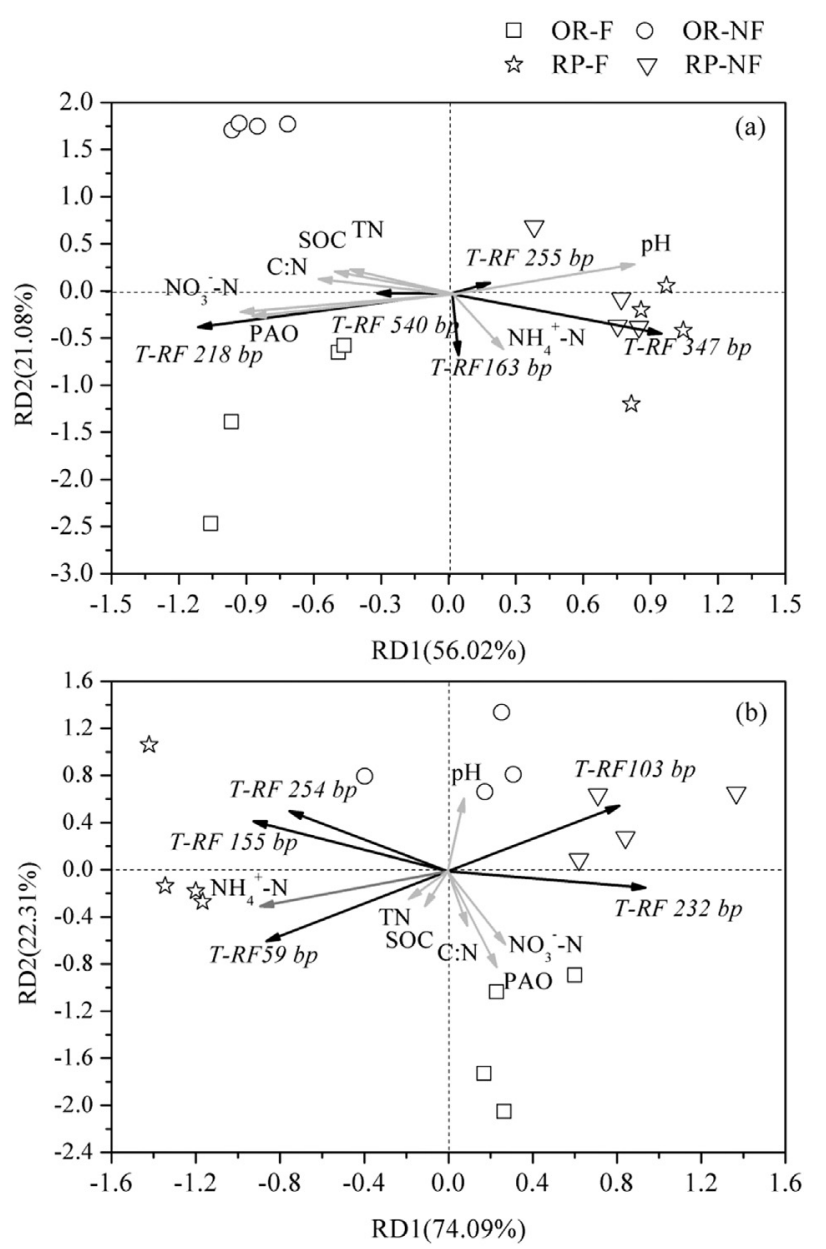

Fig. 3. RDA analysis of the community compositions of $A O A$ and $A O B$. The data are shown for the four treatments, namely, OR-F (square); OR-NF (circles); RP-F (stars); and RP-NF (triangles). The black lines represent the community compositions and the gray lines represent the soil properties.

copy numbers well fitted the linear equations both in the OR and RP (Fig. 7c and d).

\section{Discussion}

\subsection{Soil potential ammonia oxidation rates}

Land-use conversion from rice paddies to citrus orchards caused high soil ammonia oxidation rates, and fertilization significantly increased soil ammonia oxidation rates in the citrus orchards 


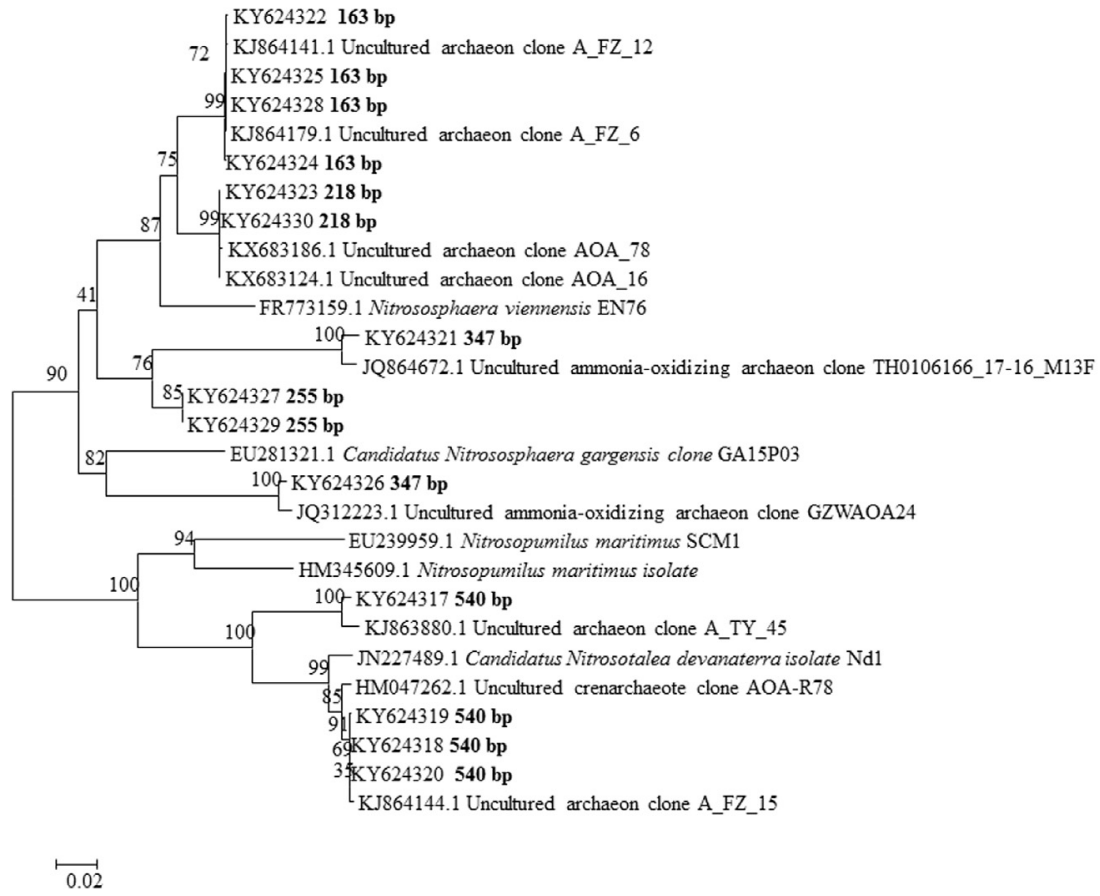

Group $1.1 \mathrm{~b}$

Group 1.1 aassociate

Group 1.1 a

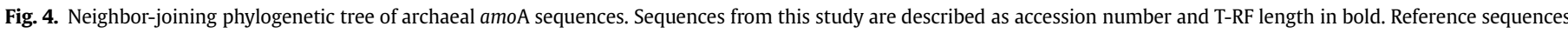
are described as clone name (accession number and environment). Bootstrap values (50\%) are indicated at branch points.

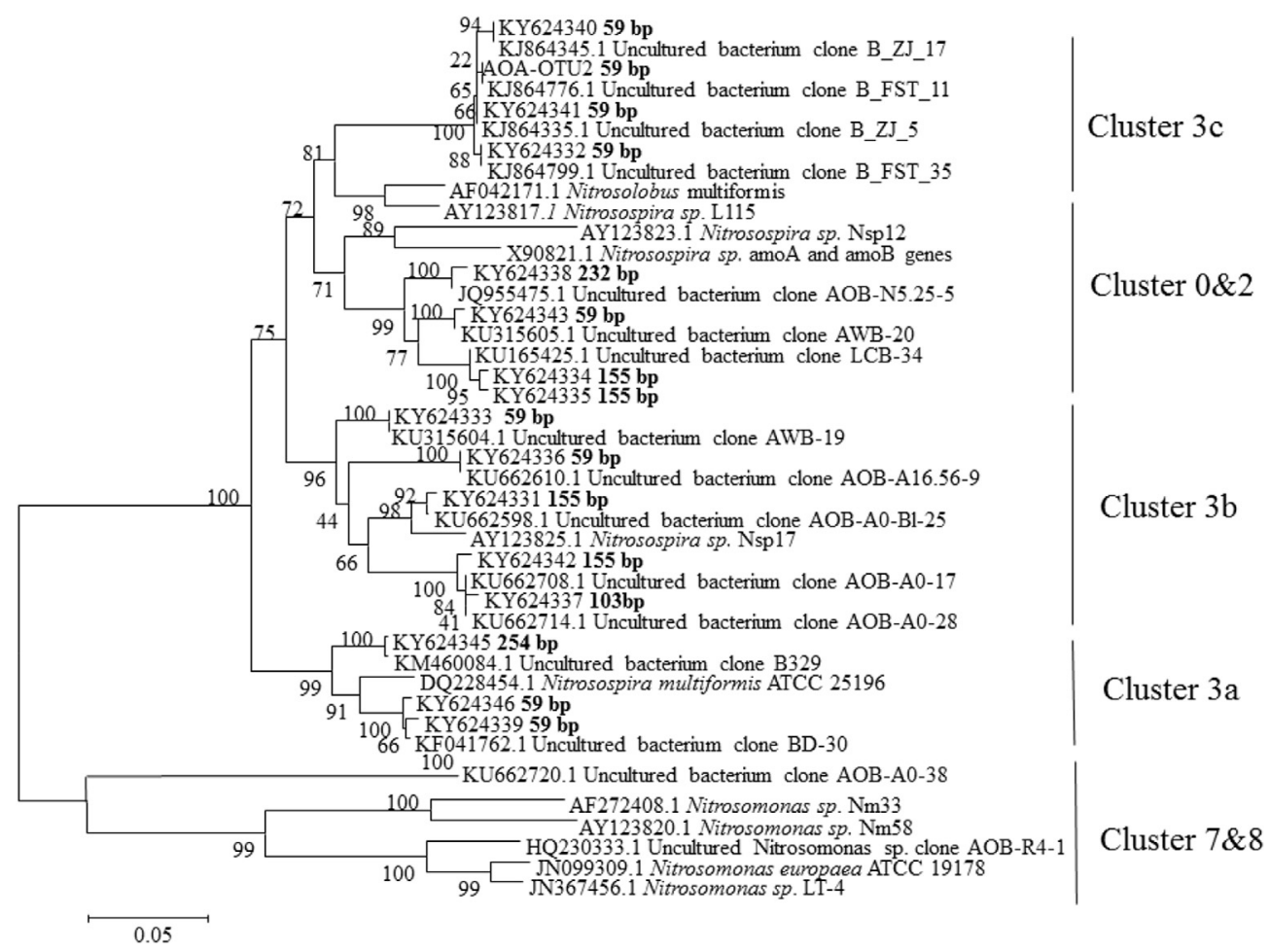

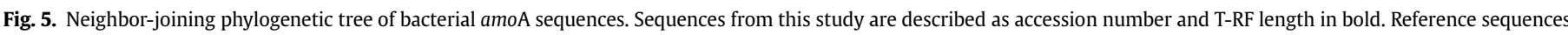
are described as clone name (accession number and environment). Bootstrap values (50\%) are indicated at branch points.

(Table 4). These findings are partly consistent with our first hypothesis that land-use conversion and fertilization could increase the soil PAO. It has been suggested that higher soil ammonia oxidation rates could be observed under the condition of nonlimiting oxygen [29,37]. In rice paddies, soil oxygen may become limited at higher soil moisture content, resulting in gas nitrogen loss through denitrification and lower or even undetectable nitrification activities [40]. After the conversion of rice paddies to citrus orchards, soil moisture regime disappeared and soil aeration enhanced (data are not shown), resulting in a significant increase in 

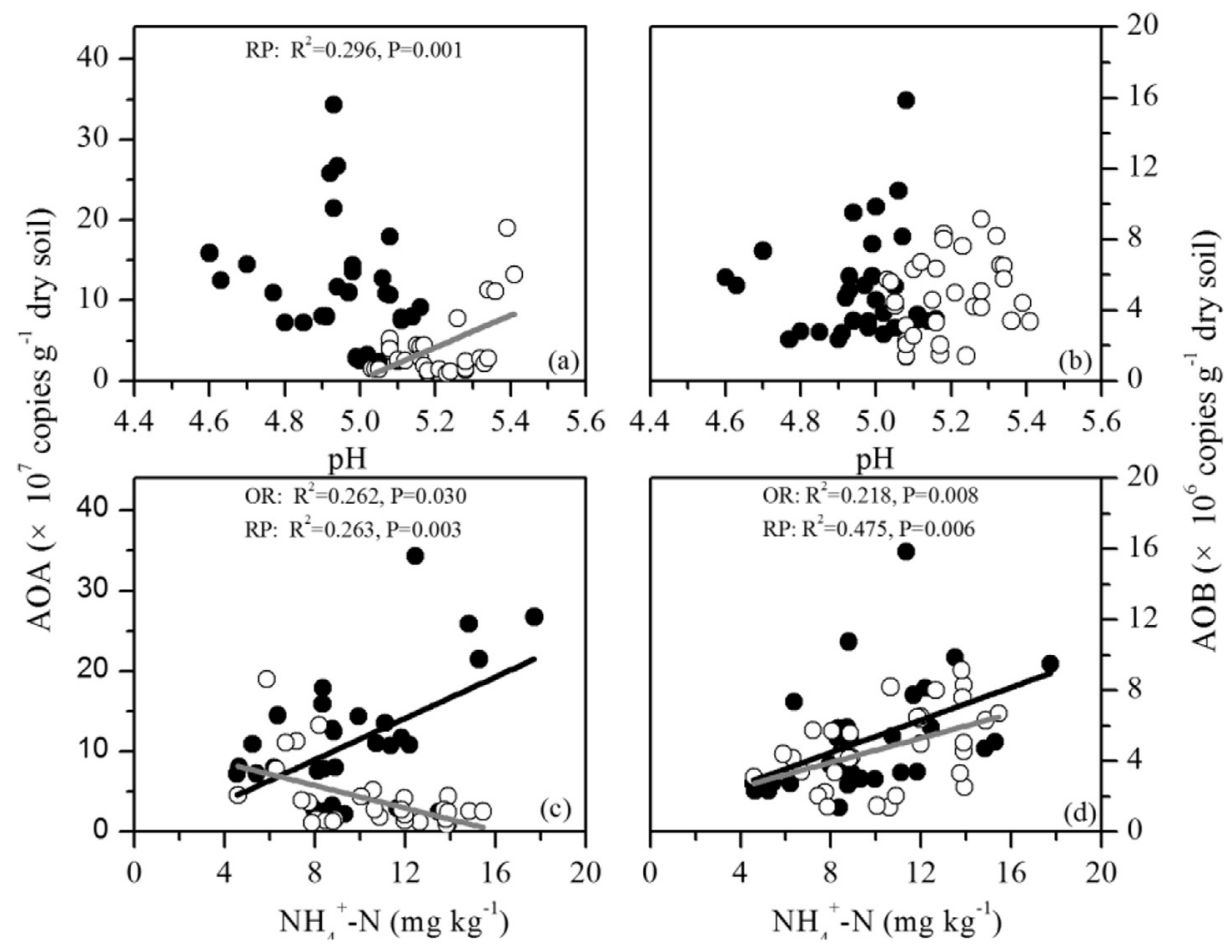

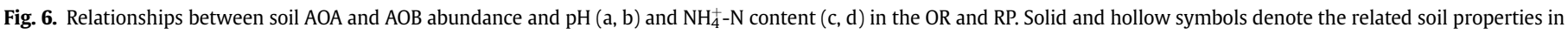
the OR and RP, respectively.
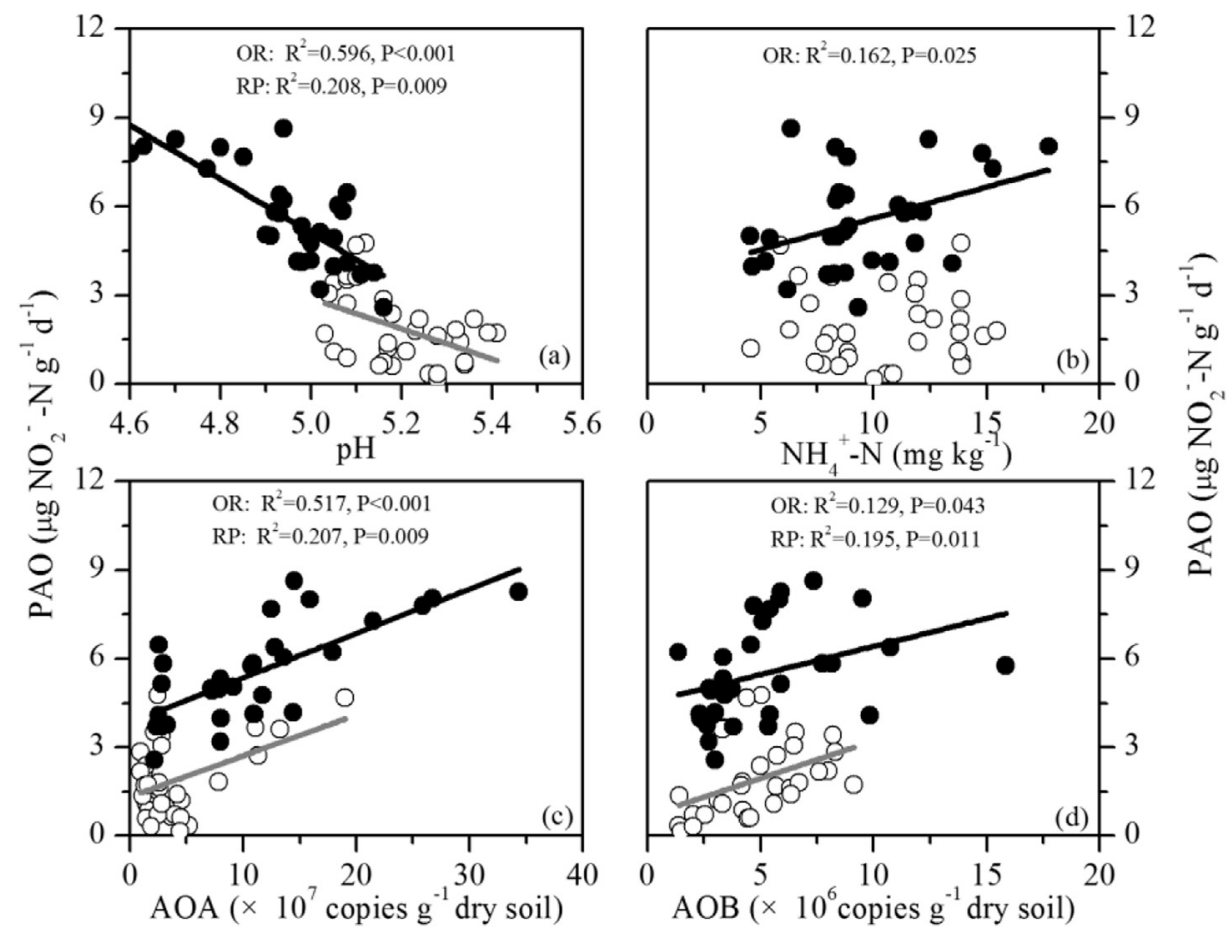

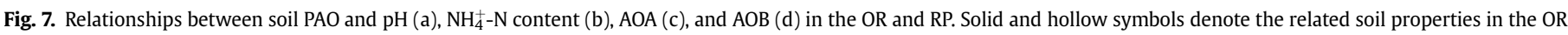
and $\mathrm{RP}$, respectively.

soil PAO (Table 4). Similarly, Sullivan et al. [24] observed higher potential nitrification rates in soils under dry conditions than wet conditions. In the present study, maximum PAO rates in the RP were observed in July, when the early-season rice had been drainage. Thus, the different patterns of PAO in the RP highlighted that soil moisture was the major determinant of the ammonia oxidation rates.

In our study, fertilization significantly increased the PAO of the $\mathrm{OR}$, which is consistent with previous findings that nitrification potential and activity significantly improved with increasing 
fertilization rate [15,41]. However, Zhong et al. [29] showed that the PAO of vegetable soils significantly decreased with increasing fertilization rates. Generally, higher amounts of $\mathrm{NH}_{4}^{+}-\mathrm{N}$ in the fertilization treatments might provide more substrates for ammonia oxidizers, thereby increase the activity of ammonia oxidation rates [42]. Nevertheless, soil acidification induced by fertilization might inhibit the growth and activity of ammonia oxidizers $[1,37,42]$. Thus, the inconsistent results could be possibly due to the counterbalance of inhibition and stimulation by soil $\mathrm{pH}$ and $\mathrm{NH}_{4}^{+}-\mathrm{N}$, respectively. In the present study, significant negative relationships between $\mathrm{PAO}$ and $\mathrm{pH}$ were observed both in the OR and RP (Fig. 7a), which are in good agreement with previous observations [37,42]. Nevertheless, as the low oxygen environment in the RP was not suitable for ammonia oxidation, the effects of fertilization were not significant.

\subsection{Abundance of ammonia oxidizers}

The average populations of $\mathrm{AOA}$ and $\mathrm{AOB}$ in the OR-F were $1.41 \times 10^{8}$ and $6.59 \times 10^{6}$ copies $g^{-1}$ dry soil, respectively, which are greater than those reported in orchards of other regions [43]. Meanwhile, the copy numbers of AOA and AOB in the RP fell in the range of those observed in other paddy soils [21,44]. Furthermore, the numbers of $A O B$ were distinctly lower than that of $A O A$ (Table 4), which is consistent with those found in other acidic agricultural soils $[30,37]$. However, AOB dominance over AOA has also been detected in the alkaline soil [45]. The contrasting results might be caused by different soil properties that provide niche specialization and differentiation of AOA and AOB [16,32].

Land-use change from rice paddies to citrus orchards increased soil AOA abundance, but did not affect AOB abundance, supporting the idea of niche differentiation between these two groups [18,44]. Then, it is possible that the increases in the AOA rather than the AOB abundance could be ascribed to a greater affinity of AOA for oxygen in the orchard soils [17,23]. However, other studies reported that $A O A$ abundance was lower in uplands than rice paddies, whereas AOB showed contrary trend $[18,37,44]$. The decreases of soil $\mathrm{pH}$ induced by land-use conversion could lead to an increase in AOA abundance, as AOA abundance are likely to increase with decreasing soil $\mathrm{pH}$ [26]. Soil $\mathrm{pH}$ values have also been recognized as one of the main variables affecting $A O B$ abundance, and increases in AOB abundance have been observed at higher soil $\mathrm{pH}[23,26]$. Meanwhile, it was also proposed that AOB populations tend to reside in the regions where oxygen levels are high [1]. The higher soil oxygen and lower soil pH in the OR than the RP might result in stable AOB abundance induced by land-use conversion.

Molecular analyses have suggested that low $\mathrm{NH}_{4}^{+}-\mathrm{N}$ environments favored the growth of AOA, whereas AOB are more competitive at higher $\mathrm{NH}_{4}^{+}-\mathrm{N}$ contents [14,19,37]. Similarly, in the present study, AOA appeared to be limited and AOB abundance increased following fertilization in the RP (Table 4). Meanwhile, in deferent soil types, AOB abundance has been found to be positively related to nitrogen fertilization, whereas AOA abundance decreased with more nitrogen added [14,29,37]. Theoretically, the decreasing soil $\mathrm{pH}$ caused by fertilization reduces soil $\mathrm{NH}_{3}$ availability because of the formation of ionized $\mathrm{NH}_{4}^{+}$, thus inhibiting the soil AOA growth [29]. Thus, the lower soil pH induced by fertilization was a greater variable than the fertilizer as a substrate for AOA in the rice paddies. Furthermore, soil AOA abundance was negatively correlated to soil $\mathrm{NH}_{4}^{+}-\mathrm{N}$ contents (Fig. 6c), but positively correlated to $\mathrm{pH}$ in the RP (Fig. 6a). In addition, fertilization stimulated AOA and AOB in the OR, which was in line with Alam et al. [18] who demonstrated that the abundance of AOA and AOB showed an increasing trend in the fertilized plots. The significant positive relationships between ammonia-oxidizers and soil $\mathrm{NH}_{4}^{+}-\mathrm{N}$ content confirmed the stimulation of fertilization (Fig. $6 \mathrm{c}$ and d).

\subsection{Community compositions of ammonia oxidizers}

Consistent with our second hypothesis, T-RFLP analysis demonstrated that land-use conversion caused distinct variations in the soil AOA and AOB communities (Fig. 3a). In a similar red soil, denaturing gradient gel electrophoresis (DGGE) fingerprints of the amoA genes showed that significant changes in the communities of AOA between uplands and rice paddies were observed [18]. Meanwhile, in an alkaline soil, ammonia-oxidizer communities (including both archaea and bacteria) in wet and dry soils were distinct from one another [22]. Therefore, land-uses could potentially be a main factor shaping the compositions of AOA and AOB. In the present study, fertilization significantly affected the AOB in the OR and RP, whereas AOA communities were only affected by fertilization in the OR (Fig. 2). Similarly, a remarkable difference in the compositions of $\mathrm{AOA}$ and $\mathrm{AOB}$ in responses to fertilization was found in an upland soil [37]. Nevertheless, in the acidic paddy soils, alterations in the AOA compositions were noted in responses to long-term fertilization managements [44]. Moreover, previous studies have also reported that AOA is more sensitive than AOB in responding to fertilization in the acidic soil, whereas $A O B$ is more sensitive to fertilization than AOA in the alkaline soil $[25,36]$. The reason for these inconsistent findings could probably be owing to the different soil $\mathrm{pH}$, initial organic nitrogen concentrations (e.g. $\mathrm{NH}_{4}^{+}-\mathrm{N} / \mathrm{NO}_{3}^{-}-\mathrm{N}>1$ or $\mathrm{NH}_{4}^{+}-\mathrm{N} / \mathrm{NO}_{3}^{-}-\mathrm{N}<1$ ), and soil oxygen availability $[23,26,43]$.

The AOA phylogenetic analysis suggested that the AOA gene sequences were aligned to group $1.1 \mathrm{~b}$ and group $1.1 \mathrm{a}$, whereas the T-RF 540 bp belonging to the group 1.1 a showed the highest relative abundance. These results were in well agreement with former studies that group 1.1a could possibly be more abundant in acidic red soils, while group $1.1 \mathrm{~b}$ was more adaptable to neutral and alkaline soils $[21,46]$. Former results also suggested that the group 1.1a-associated lineage could possibly be tolerant with limiting oxygen than soil group $1.1 \mathrm{~b}$ [18]. Our results demonstrated that the environmental factors induced by land-use conversion determined the phylogenetically AOA also depend on the fertilization management (Fig .3a). The AOB phylogenetic analyses showed that Nitrosospira cluster like AOB exclusively predominate the community compositions of bacterial ammonia-oxidizers in acidic red soils, which were in line with results obtained from former agriculture soils $[37,46]$. It was proposed that AOB belonged to Nitrosomonas spp (cluster $7 \& 8$ ) were exclusively detected in the rice paddies, whereas AOB within Nitrosospira spp (cluster $2 \& 0$ ) was observed only in the upland soils $[37,46]$. However, no such distinct phenomenon was observed in our study, which might relate to the soil samplings used for the physiological analysis (day in the drainage period). Moreover, relationships among oxygen contents, soil properties, and AOA and AOB in agricultural soils should be concerned in the further study.

\subsection{Correlations between soil ammonia oxidation and ammonia- oxidizer communities}

The relative roles of $\mathrm{AOA}$ and $\mathrm{AOB}$ in the ammonia oxidization remain uncertain, and contradictory results had been observed in different ecosystems [14,47]. In a long-term fertilization study, Wessen et al. [47] analyzed the nitrification process and observed that only the AOA were significantly related to this process. In a nitrogen-rich grassland soil and cropped soils, AOB not AOA are functionally more important in ammonia oxidation [13,14]. However, it was also revealed that potential nitrification activities were dependent on substrate availability and soil properties, rather than 
AOA or AOB dominance [9]. In our study, both $A O B$ and AOA abundance were linearly correlated to the PAO in the OR and RP (Fig. 7c and d), confirming our third hypothesis that both AOA and AOB are closely closed to the ammonia oxidation rates. Similar findings have also been documented by He et al. [37] in acidic red soils and Szukics et al. [23] in temperate acidic soils. Moreover, RDA analysis also suggested that the PAO were more closely correlated to the T-RF of $218 \mathrm{bp}$ belonged to group $1.1 \mathrm{~b}$ retrieved from AOA sequence (Fig. 3a). Similarly, ammonia oxidization by the group $1.1 \mathrm{~b}$ has recently been observed in some acid soils [48]. Nevertheless, we could not conclude that the only specific group $1.1 \mathrm{~b}$ contributed more to soil ammonia oxidation, as that the metabolic characteristics and ecological functions of AOA are still unclear [34]. More studies, such as stable isotope tracing and specific inhibition of $A O A$ or $A O B$, are urgently needed to find the relative roles of $A O A$ and $A O B$ in ammonia oxidation in different soil types.

\section{Conclusions}

Overall, the present study demonstrated that the conversion of rice paddies to citrus orchards stimulated the potential ammonia oxidation, whereas fertilization only increased the potential ammonia oxidation in the citrus orchards. Land-use conversion from rice paddies to citrus orchards increased AOA abundance, had no impact on the $A O B$ abundance, altered the communities of $A O A$ and AOB. Moreover, fertilization significantly increased the AOB abundance, and affected the compositions of $A O B$ in the rice paddies and citrus orchards. Nevertheless, the responses of abundance and compositions of AOA to fertilization highly depended on the land-use types. Furthermore, phylogenetic analysis revealed that Nitrosospira cluster-like AOB were the predominant groups of bacterial ammonia-oxidizers, whereas the soil group 1.1a lineage predominate the community compositions of AOA in this acidic red soil. Moreover, ammonia oxidation rates were significantly correlated to AOA and AOB abundance, confirming the intimate linkage between soil ammonia oxidizers and ammonia oxidation rates. Moreover, RDA analysis suggested that the ammonia oxidation were intimately related to the group $1.1 \mathrm{~b}$ lineage of AOA.

\section{Acknowledgements}

This work was supported by the National Natural Science Foundation of China (41471095), the National Key Research and Development Program of China (2016YFC0502102), and the Ministry of Science and Technology of China (2012CB417103). We would thanks the staffs from Qianyanzhou Experimental Station for their fruitful help in field sampling. Special thanks go to the anonymous reviewers for constructive comments on the previous version of the manuscript.

\section{References}

[1] G.A. Kowalchuk, J.R. Stephen, Ammonia-oxidizing bacteria: a model for molecular microbial ecology, Annu. Rev. Microbiol. 55 (2001) 485-529.

[2] M. Gödde, R. Conrad, Immediate and adaptational temperature effects on nitric oxide production and nitrous oxide release from nitrification and denitrification in two soils, Biol. Fert. Soils 30 (1999) 33-40.

[3] J.I. Prosser, G.W. Nicol, Relative contributions of archaea and bacteria to aerobic ammonia oxidation in the environment, Environ. Microbiol. 10 (2008) 2931-2941.

[4] M.B. Lund, J.M. Smith, C.A. Francis, Diversity, abundance and expression of nitrite reductase (nirK)-like genes in marine thaumarchaea, ISME J. 6 (2012) 1966-1977.

[5] J.C. Venter, K. Remington, J.F. Heidelberg, A.L. Halpern, D. Rusch, J.A. Eisen, D. Wu, I. Paulsen, K.E. Nelson, W. Nelson, Environmental genome shotgun sequencing of the Sargasso Sea, Science 304 (2004) 66-74.

[6] M. Könneke, A.E. Bernhard, R. José, C.B. Walker, J.B. Waterbury, D.A. Stahl, Isolation of an autotrophic ammonia-oxidizing marine archaeon, Nature 437 (2005) 543-546.
[7] C. Wuchter, B. Abbas, M.J. Coolen, L. Herfort, J. van Bleijswijk, P. Timmers, M. Strous, E. Teira, G.J. Herndl, J.J. Middelburg, Archaeal nitrification in the ocean, P. Natl. Sci. 103 (2006) 12317-12322.

[8] R. Hatzenpichler, E.V. Lebedeva, E. Spieck, K. Stoecker, A. Richter, H. Daims, M. Wagner, A moderately thermophilic ammonia-oxidizing crenarchaeote from a hot spring, P. Natl. Sci. 105 (2008) 2134-2139.

[9] Y. Ouyang, J.M. Norton, J.M. Stark, J.R. Reeve, M.Y. Habteselassie, Ammoniaoxidizing bacteria are more responsive than archaea to nitrogen source in an agricultural soil, Soil. Biol. Biochem. 96 (2016) 4-15.

[10] J. Ying, X. Li, N. Wang, Z. Lan, J. He, Y. Bai, Contrasting effects of nitrogen forms and soil $\mathrm{pH}$ on ammonia oxidizing microorganisms and their responses to long-term nitrogen fertilization in a typical steppe ecosystem, Soil. Biol. Biochem. 107 (2017) 10-18.

[11] S. Leininger, T. Urich, M. Schloter, L. Schwark, J. Qi, G. Nicol, J. Prosser, S. Schuster, C. Schleper, Archaea predominate among ammonia-oxidizing prokaryotes in soils, Nature 442 (2006) 806-809.

[12] H.J. Di, K.C. Cameron, J.P. Shen, C.S. Winefield, M. O'Callaghan, S. Bowatte, J.Z. He, Ammonia-oxidizing bacteria and archaea grow under contrasting soil nitrogen conditions, FEMS Microbiol. Ecol. 72 (2010) 386-394.

[13] A.E. Taylor, L.H. Zeglin, S. Dooley, D.D. Myrold, P.J. Bottomley, Evidence for different contributions of archaea and bacteria to the ammonia-oxidizing potential of diverse Oregon soils, Appl. Environ. Microbiol. 76 (2010) $7691-7698$.

[14] H. Di, K. Cameron, J.P. Shen, C. Winefield, M. O'Callaghan, S. Bowatte, J. He, Nitrification driven by bacteria and not archaea in nitrogen-rich grassland soils, Nat. Geosci. 2 (2009) 621-624.

[15] C. Ai, G. Liang, J. Sun, X. Wang, P. He, W. Zhou, Different roles of rhizosphere effect and long-term fertilization in the activity and community structure of ammonia oxidizers in a calcareous fluvo-aquic soil, Soil. Biol. Biochem. 57 (2013) 30-42.

[16] K. Schauss, A. Focks, S. Leininger, A. Kotzerke, H. Heuer, S. Thiele-Bruhn, S. Sharma, B.M. Wilke, M. Matthies, K. Smalla, J.C. Munch, W. Amelung, M. Kaupenjohann, M. Schloter, C. Schleper, Dynamics and functional relevance of ammonia-oxidizing archaea in two agricultural soils, Environ. Microbiol. 11 (2009) 446-456.

[17] C. Fujii, T. Nakagawa, Y. Onodera, N. Matsutani, K. Sasada, R. Takahashi, T. Tokuyama, Succession and community composition of ammonia-oxidizing archaea and bacteria in bulk soil of a Japanese paddy field, Soil. Sci. Plant. Nutr. 56 (2010) 212-219.

[18] M.S. Alam, G.D. Ren, L. Lu, Y. Zheng, X.H. Peng, Z.J. Jia, Conversion of upland to paddy field specifically alters the community structure of archaeal ammonia oxidizers in an acid soil, Biogeosciences 10 (2013) 5739-5753.

[19] H.J. Di, K.C. Cameron, R.R. Sherlock, J.P. Shen, J.Z. He, C.S. Winefield, Nitrous oxide emissions from grazed grassland as affected by a nitrification inhibitor, dicyandiamide, and relationships with ammonia-oxidizing bacteria and archaea, J. Soil Sediment. 10 (2010) 943-954.

[20] T.H. Erguder, N. Boon, L. Wittebolle, M. Marzorati, W. Verstraete, Environmental factors shaping the ecological niches of ammonia-oxidizing archaea, FEMS Microbiol. Rev. 33 (2009) 855-869.

[21] Z. Jia, R. Conrad, Bacteria rather than Archaea dominate microbial ammonia oxidation in an agricultural soil, Environ. Microbiol. 11 (2009) 1658-1671.

[22] D.B. Gleeson, C. Müller, S. Banerjee, W. Ma, S.D. Siciliano, D.V. Murphy, Response of ammonia oxidizing archaea and bacteria to changing water filled pore space, Soil. Biol. Biochem. 42 (2010) 1888-1891.

[23] U. Szukics, E. Hackl, S. Zechmeister-Boltenstern, A. Sessitsch, Rapid and dissimilar response of ammonia oxidizing archaea and bacteria to nitrogen and water amendment in two temperate forest soils, Microbiol. Res. 167 (2012) 103-109.

[24] B.W. Sullivan, P.C. Selmants, S.C. Hart, New evidence that high potential nitrification rates occur in soils during dry seasons: are microbial communities metabolically active during dry seasons? Soil. Biol. Biochem. 53 (2012) 28-31.

[25] Y. Chen, Z. Xu, H. Hu, Y. Hu, Z. Hao, Y. Jiang, B. Chen, Responses of ammoniaoxidizing bacteria and archaea to nitrogen fertilization and precipitation increment in a typical temperate steppe in Inner Mongolia, Appl. Soil. Ecol. 68 (2013) 36-45

[26] G.W. Nicol, S. Leininger, C. Schleper, J.I. Prosser, The influence of soil pH on the diversity, abundance and transcriptional activity of ammonia oxidizing archaea and bacteria, Environ. Microbiol. 10 (2008) 2966-2978.

[27] C. Gubry-Rangin, B. Hai, C. Quince, M. Engel, B.C. Thomson, P. James, M. Schloter, R.I. Griffiths, J.I. Prosser, G.W. Nicol, Niche specialization of terrestrial archaeal ammonia oxidizers, P. Natl. Sci. 108 (2011) 21206-21211.

[28] J.I. Prosser, G.W. Nicol, Archaeal and bacterial ammonia-oxidisers in soil: the quest for niche specialisation and differentiation, Trends Microbiol. 20 (2012) $523-531$.

[29] W. Zhong, B. Bian, N. Gao, J. Min, W. Shi, X. Lin, W. Shen, Nitrogen fertilization induced changes in ammonia oxidation are attributable mostly to bacteria rather than archaea in greenhouse-based high $\mathrm{N}$ input vegetable soil, Soil. Biol. Biochem. 93 (2016) 150-159.

[30] J.P. Shen, P. Cao, H.W. Hu, J.Z. He, Differential response of archaeal groups to land use change in an acidic red soil, Sci. Total. Environ. 461 (2013) 742-749.

[31] D.R. Lammel, K. Nuesslein, S.M. Tsai, C.C. Cerri, Land use, soil and litter chemistry drive bacterial community structures in samples of the rainforest and Cerrado (Brazilian Savannah) biomes in Southern Amazonia, Eur. J. Soil Biol. 66 (2015) 32-39. 
[32] W. Martens-Habbena, P.M. Berube, H. Urakawa, J.R. de la Torre, D.A. Stahl, Ammonia oxidation kinetics determine niche separation of nitrifying Archaea and Bacteria, Nature 461 (2009) 976-979.

[33] Y. Wu, L. Lu, B. Wang, X. Lin, J. Zhu, Z. Cai, X. Yan, Z. Jia, Long-term field fertilization significantly alters community structure of ammonia-oxidizing bacteria rather than archaea in a paddy soil, Soil Sci. Soc. Am. J. 75 (2011) $1431-1439$

[34] C. Walker, J. De La Torre, M. Klotz, H. Urakawa, N. Pinel, D. Arp, C. BrochierArmanet, P. Chain, P. Chan, A. Gollabgir, Nitrosopumilus maritimus genome reveals unique mechanisms for nitrification and autotrophy in globally distributed marine crenarchaea, P. Natl. Sci. 107 (2010) 8818-8823.

[35] J.P. Shen, L.m. Zhang, Y.G. Zhu, J.b. Zhang, J.Z. He, Abundance and composition of ammonia-oxidizing bacteria and ammonia-oxidizing archaea communities of an alkaline sandy loam, Environ. Microbiol. 10 (2008) 1601-1611.

[36] X. Chen, L.M. Zhang, J.P. Shen, Z. Xu, J.Z. He, Soil type determines the abundance and community structure of ammonia-oxidizing bacteria and archaea in flooded paddy soils, J. Soil Sediment. 10 (2010) 1510-1516.

[37] J.Z. He, J.P. Shen, L.M. Zhang, Y.G. Zhu, Y.M. Zheng, M.G. Xu, H. Di, Quantitative analyses of the abundance and composition of ammonia-oxidizing bacteria and ammonia-oxidizing archaea of a Chinese upland red soil under long-term fertilization practices, Environ. Microbiol. 9 (2007) 2364-2374.

[38] H. Liu, G. Liu, Y. Li, X. Wu, D. Liu, X. Dai, M. Xu, F. Yang, Effects of land use conversion and fertilization on $\mathrm{CH}_{4}$ and $\mathrm{N}_{2} \mathrm{O}$ fluxes from typical hilly red soil, Environ. Sci. Pollut. Res. 23 (2016) 20269-20280.

[39] J. Kurola, M. Salkinoja-Salonen, T. Aarnio, J. Hultman, M. Romantschuk, Activity, diversity and population size of ammonia-oxidising bacteria in oilcontaminated landfarming soil, Fems Microbiol. Lett. 250 (2005) 33-38.

[40] U. Szukics, E. Hackl, S. Zechmeister-Boltenstern, A. Sessitsch, Contrasting response of two forest soils to nitrogen input: rapidly altered $\mathrm{NO}$ and $\mathrm{N}_{2} \mathrm{O}$ emissions and nirK abundance, Biol. Fert. Soils 45 (2009) 855-863.

41] S. Wertz, A.K.K. Leigh, S.J. Grayston, Effects of long-term fertilization of forest soils on potential nitrification and on the abundance and community structure of ammonia oxidizers and nitrite oxidizers, FEMS Microbiol. Ecol. 79 (2012) 142-154.

[42] J. Wang, L. Gang, L. Xin, S. Xiaolong, Z. Jianning, Y. Dianlin, Differential responses of ammonia-oxidizers communities to nitrogen and water addition inStipa baicalensisSteppe, inner Mongolia, northern China, J. Res. Ecol. 6 (2015) 1-11.

[43] H. Yao, Y. Gao, G.W. Nicol, C.D. Campbell, J.I. Prosser, L. Zhang, W. Han, B.K. Singh, Links between ammonia oxidizer community structure, abundance, and nitrification potential in acidic soils, Appl. Environ. Microb. 77 (2011) 4618-4625.

[44] X. Chen, L.M. Zhang, J.P. Shen, W.X. Wei, J.Z. He, Abundance and community structure of ammonia-oxidizing archaea and bacteria in an acid paddy soil Biol. Fert. Soils 47 (2011) 323-331.

[45] G. Azziz, T. Trasante, J. Monza, P. Irisarri, The effect of soil type, rice cultivar and water management on ammonia-oxidizing archaea and bacteria populations, Appl. Soil. Ecol. 100 (2016) 8-17.

[46] Q. Wang, L.M. Zhang, J.P. Shen, S. Du, L.L. Han, J.Z. He, Effects of dicyandiamide and acetylene on $\mathrm{N}_{2} \mathrm{O}$ emissions and ammonia oxidizers in a fluvo-aquic soil applied with urea, Environ. Sci. Pollut. Res. 23 (2016) 23023-23033.

47] E. Wessen, K Nyberg JK. Jansson, S. Hallin, Responses of bacterial and archaeal ammonia oxidizers to soil organic and fertilizer amendments under long-term management, Appl. Soil. Ecol. 45 (2010) 193-200.

[48] B. Wang, Y. Zheng, R. Huang, X. Zhou, D. Wang, Y. He, Z. Jia, Active ammonia oxidizers in an acidic soil are phylogenetically closely related to neutrophilic archaeon, Appl. Environ. Microbiol. 80 (2014) 1684-1691. 